\title{
Neutron Activation Analysis and Assessment of Trace Elements in Fingernail from Residents of Tokyo, Japan
}

(Analisis Pengaktifan Neutron dan Penilaian Unsur Surih dalam Kuku Penduduk di Tokyo, Jepun)

\author{
B.S. WEE* \& M. EBIHARA
}

\begin{abstract}
We report herewith the study of fingernail clippings obtained from the residents of Tokyo, Japan. A total of 18 participants with no health problems and occupational exposure to metals were recruited to provide fingernails samples for this study. Through the use of instrumental neutron activation analysis (INAA), 18 elements (Ag, Al, $\mathrm{As}, \mathrm{Ca}, \mathrm{Cl}, \mathrm{Co}, \mathrm{Cu}, \mathrm{Fe}, \mathrm{Hg}, \mathrm{K}$, $\mathrm{Mg}, \mathrm{Mn}, \mathrm{Na}, \mathrm{S}, \mathrm{Sb}, \mathrm{Se}, \mathrm{V}$, and $\mathrm{Zn}$ ) were determined. The results showed that the toxic elements in the fingernails are in the lower range when compared to literature values. There were no chronic exposures to toxic elements such as As and $\mathrm{Hg}$ found. The level of $\mathrm{Hg}$ found is lower than that reported 20 years ago, possibly due to the strict regulation control in Japan on the release of $\mathrm{Hg}$ to the environment. The elements Se and Zn are found to be rather uniformly distributed among participants and are in agreement with results from other countries. There were no significant differences in elemental concentrations due to genders and smoking habits. The overall data from this study showed similar concentrations to those of healthy participants from other countries. Thus, the current data could represent the background level of elemental concentrations in fingernails of residents in Tokyo, which could serve as reference values for future study.
\end{abstract}

Keywords: Fingernail; neutron activation analysis; trace elements

\section{ABSTRAK}

Kajian ini melaporkan mengenai keratan kuku yang diperoleh daripada penduduk Tokyo, Jepun. Seramai 18 orang subjek yang tidak mempunyai masalah kesihatan dan pendedahan kepada logam telah direkrut bagi menyediakan sampel kuku dalam kajian ini. Melalui penggunaan instrumental analisis pengaktifan neutron (INAA), 18 unsur-unsur ( $\mathrm{Ag}, \mathrm{Al}, \mathrm{As}, \mathrm{Ca}, \mathrm{Cl}, \mathrm{Co}, \mathrm{Cu}, \mathrm{Fe}, \mathrm{Hg}, \mathrm{K}, \mathrm{Mg}, \mathrm{Mn}, \mathrm{Na}, \mathrm{S}, \mathrm{Sb}, \mathrm{Se}, \mathrm{V}$ dan $\mathrm{Zn}$ ) telah ditentukan. Hasil kajian menunjukkan bahawa unsur toksik dalam kuku berada dalam keadaan yang lebih rendah apabila dibandingkan dengan nilai daripada sumber rujukan. Tiada pendedahan kronik kepada unsur toksik seperti As dan Hg telah dijumpai. Didapati bahawa tahap Hg adalah lebih rendah daripada yang dilaporkan 20 tahun yang lalu, berkemungkinan disebabkan oleh kawalan peraturan yang ketat di Jepun dalam membebaskan Hg ke alam sekitar. Penyebaran unsur Se dan Zn juga didapati agak seragam dalam kalangan peserta dan keputusan ini juga sama seperti negara-negara lain. Tiada perbezaan yang signifikan dalam kepekatan unsur yang disebabkan oleh faktor jantina dan tabiat merokok. Keseluruhan data kajian ini telah menunjukkan kepekatan yang sama dengan subjek sihat dari negara lain. Oleh itu, data semasa dapat mewakili tahap latar belakang kepekatan unsur dalam kuku penduduk di Tokyo, yang boleh dijadikan sebagai nilai rujukan untuk kajian pada masa hadapan.

Kata kunci: Analisis pengaktifan neutron; keratan kuku; unsur surih

\section{INTRODUCTION}

Biological tissues such as nails have been utilized as biomonitor for evaluating the environmental pollution level through the studies of trace element composition. Thus, individuals exposed to environmental pollution could be diagnosed through the abnormality of trace element concentrations in nail samples. The reason for using fingernails as diagnostic material is that trace elements accumulated in the nails can reflect the long term exposure to environmental pollution (Menezes et al. 2004). It is known that chemical composition of nail is stable after its formation and will not be affected by blood chemistry or chemical exposure (Daniel III et al. 2004). Besides those, nails can be easily collected and stored at normal room temperature prior to analysis and small amounts of samples (about $10 \mathrm{mg}$ ) are sufficient for chemical analysis.

The chemical compositions of nails may be related to gender, nutrition, occupation, age, disease and season. Hayashi et al. (1993) showed that $\mathrm{Cd}$ and $\mathrm{Pb}$ in nails of males are higher than those of females. They argue that higher $\mathrm{Cd}$ and $\mathrm{Pb}$ in males are attributed to outdoor activities or higher dietary intake. Arsenic concentration anomalies (mean of $7.24 \mu \mathrm{g} / \mathrm{g}$ ) in nails have been used as an indicator for arsenic poisoning in residents of West Bengal, India, which is caused by consumption of water polluted with arsenic (Samanta et al. 2004). The high concentrations of $\mathrm{Cl}, \mathrm{Cr}, \mathrm{K}$ and 
$\mathrm{Na}$ in nails can be used as the indicators for person with cystic fibrosis disease (Aguiar \& Saiki 2001). On the other hand, patients infected with Schistosoma mansoni showed increased level of $\mathrm{Al}, \mathrm{Cl}$, I and $\mathrm{Br}$ in fingernails compared to healthy individuals (El-Khatib et al. 1995). Thus, elemental concentrations in nails can be a useful indicator for disease diagnosis. Besides, individuals from different regions exhibit variable pattern of trace element concentrations as reported by Takagi et al. (1988) in an international comparison study of nail samples collected from Japan, India, U.S.A, Canada and Poland. Takagi et al. (1988) suggested that dietary intake and living habits of individuals from different regions may affect the trace element concentrations in nails.

There are many analytical techniques usable for the determinations of element concentrations in nails such as atomic absorption spectrometry (Hayashi et al. 1993) and inductively coupled plasma mass spectrometry (Samanta et al. 2004). In this study, instrumental neutron activation analysis (INAA) was selected for the analysis of fingernail samples because of its simple sample preparation and multi-element analysis capability. By using different irradiation and counting schemes, many elements with variable half-lives could be determined reliably. Several studies utilizing INAA for multi-elemental analysis of nail samples have been reported (Aguiar \& Saiki 2001; Chaudhary et al. 1995; Cheng et al. 1995; El-Khatib et al. 1995; Menezes et al. 2004; Morris et al. 2006).

In this study, the individuals recruited were university students and staff who stay around the area of MinamiOsawa, Tokyo. Their dietary habits are typical Japanese food consisted of rice, fish, meat and vegetables. They eat at school restaurant during lunch and dinner and drink green tea after each meal. Among the individuals, five were habitual smokers whereas the remaining were non-smokers. To the best of our knowledge, there is no published data on the study of trace elements in fingernails from the residents of Tokyo. Furthermore, multi-elemental analyses of fingernail samples of Japanese are scarcely reported. Thus, this study aims to present the results of trace element concentrations in fingernails obtained from healthy individuals residing in suburban area of Tokyo. In addition, the results from this study were compared to data from literatures reporting elemental concentrations in nail samples.

\section{MATERIALS AND METHODS}

\section{SAMPLE COLLECTION AND PREPARATION}

The participants of this study are healthy and nonexposed individuals who stay in suburban Tokyo and its vicinity. A total of 18 individuals (11 males, 7 females) participated in this study with an average age of 27.7 years old. Fingernail samples (from 10 fingers) were collected from the participants using a clipper and kept in polyethylene bags. The samples were then transferred to clean beakers and washed with acetone for $20 \mathrm{~min}$ in ultrasonic bath. Then, the nail samples were washed twice with deionized water (MilliQ) for $20 \mathrm{~min}$. Finally, the samples were washed again with acetone for $20 \mathrm{~min}$ and dried on a clean bench overnight. After drying, the samples were kept in acid-cleaned glass bottles.

\section{SAMPLE IRRADIATIONS AND DATA ANALYSES}

About 10 - 40 mg of fingernail was double-sealed in acidcleaned polyethylene bags prior to irradiation. The NIST $1566 \mathrm{~b}$ (Oyster Tissue) was used as a reference standard for the quantification of elemental concentrations, while the NIES No. 5 (Human Hair) and NIST 1577a (Bovine Liver) were analyzed as quality control materials. These control samples were properly dried (at $85^{\circ} \mathrm{C}$ for $4 \mathrm{~h}$ ) prior to irradiation. The moisture contents of NIES No. 5 (Human Hair) and NIST 1577a (Bovine Liver) were 7.4 and $3.8 \%$, respectively. Several 10s mg of reference and control materials were used for irradiation. The neutronirradiation was performed at the research reactor of Japanese Atomic Energy Agency with a thermal neutron flux of about $10^{13} \mathrm{n} / \mathrm{cm}^{2} / \mathrm{s}$. All the samples, reference standard and quality control materials were firstly subjected to $2 \mathrm{~min}$ irradiations and measured for $\gamma$-rays emitted by short-lived radionuclides for $5 \mathrm{~min}$. Then, the samples were secondly irradiated for $20 \mathrm{~min}$ and their $\gamma$-rays were measured 2 to 3 times with different decay intervals in order to detect radionuclides of variable half-lives. The radionuclides used for determination of elemental concentrations are listed in Table 1. Relative method was used for the quantification of elemental concentrations in the fingernail samples and the quality control materials. All results were presented as dry weight basis.

The results obtained in this study were analyzed using $t$-test to evaluate the difference in terms of gender and smoking habit. When a probability value $(P)$ is smaller than 0.05 , the difference was considered to be significant. In addition, the compositional relationships among elements in fingernails are evaluated by using correlation matrix.

\section{RESULTS AND DISCUSSION}

\section{ANALYTICAL QUALITY CONTROL}

The NIES No. 5 (Human Hair) and NIST 1577a (Bovine Liver) were analyzed as analytical quality control samples using INAA technique. These two reference materials were used because many trace elements are certified and suitable as analytical quality controls for fingernail analysis. Their results could be cross-referenced to ensure the reliability of the procedure. The results obtained were presented in Table 2 and compared with literature values. $\mathrm{The} \mathrm{Hg}$ value for NIES No. 5 (Human Hair) was found to be significantly lower than a certified value. This could be due to vitalization of $\mathrm{Hg}$ during irradiation. This could suggest 
TABLE 1. Radionuclides (arranged in increasing half-life) used for the determination of elemental concentrations in fingernails

\begin{tabular}{cccc}
\hline Element & Radionuclide & Half-life & $\gamma$-ray energy $(\mathrm{keV})^{*}$ \\
\hline $\mathrm{Al}$ & ${ }^{28} \mathrm{Al}$ & $2.24 \mathrm{~m}$ & 1778.7 \\
$\mathrm{~V}$ & ${ }^{52} \mathrm{~V}$ & $3.76 \mathrm{~m}$ & 1434.1 \\
$\mathrm{~S}$ & ${ }^{37} \mathrm{~S}$ & $5.06 \mathrm{~m}$ & 3104 \\
$\mathrm{Cu}$ & ${ }^{66} \mathrm{Cu}$ & $5.10 \mathrm{~m}$ & 1039.2 \\
$\mathrm{Ca}$ & ${ }^{49} \mathrm{Ca}$ & $8.72 \mathrm{~m}$ & 3084.4 \\
$\mathrm{Mg}$ & ${ }^{27} \mathrm{Mg}$ & $9.46 \mathrm{~m}$ & 1014.4 \\
$\mathrm{Cl}$ & ${ }^{38} \mathrm{Cl}$ & $37.3 \mathrm{~m}$ & 1642.2 \\
$\mathrm{Mn}$ & ${ }^{56} \mathrm{Mn}$ & $2.58 \mathrm{~h}$ & 1810.7 \\
$\mathrm{~K}$ & ${ }^{42} \mathrm{~K}$ & $12.36 \mathrm{~h}$ & 1524.6 \\
$\mathrm{Na}$ & ${ }^{24} \mathrm{Na}$ & $15.02 \mathrm{~h}$ & 1368.5 \\
$\mathrm{As}$ & ${ }^{76} \mathrm{As}$ & $26.3 \mathrm{~h}$ & 559.1 \\
$\mathrm{Sb}$ & ${ }^{122} \mathrm{Sb}$ & $2.7 \mathrm{~d}$ & 564.4 \\
$\mathrm{Fe}$ & ${ }^{59} \mathrm{Fe}$ & $44.5 \mathrm{~d}$ & 1292 \\
$\mathrm{Hg}$ & ${ }^{203} \mathrm{Hg}$ & $46.8 \mathrm{~d}$ & 279.2 \\
$\mathrm{Se}$ & ${ }^{75} \mathrm{Se}$ & $118.5 \mathrm{~d}$ & 264 \\
$\mathrm{Zn}$ & ${ }^{65} \mathrm{Zn}$ & $224.1 \mathrm{~d}$ & 1115 \\
$\mathrm{Ag}$ & ${ }^{110 \mathrm{~m}} \mathrm{Ag}$ & $252 \mathrm{~d}$ & 657.7 \\
$\mathrm{Co}$ & ${ }^{60} \mathrm{Co}$ & $5.27 \mathrm{y}$ & 1332.5 \\
\hline
\end{tabular}

* The $\gamma$-ray energies used for quantifications of elemental concentrations

that $\mathrm{Hg}$ in hair is bonded less strongly than $\mathrm{Hg}$ in bovine liver tissues. Except for $\mathrm{Hg}$, our values are in agreement with certified and literature values within $\pm 15 \%$ for most of the elements determined. Therefore, data obtained for fingernails in this study can be acceptable for further discussions.

\section{ELEMENTAL CONCENTRATIONS IN FINGERNAILS}

Data of 18 elements in fingernail samples determined using INAA are compiled in Table 3. Among these elements, $\mathrm{S}$ is the most abundant with a mean value of $33600 \mu \mathrm{g} / \mathrm{g}$. Mean concentrations of $\mathrm{Ca}, \mathrm{Cl}, \mathrm{Mg}$ and $\mathrm{Zn}$ range from 77 to $464 \mu \mathrm{g} / \mathrm{g}$, while those of $\mathrm{Ag} \mathrm{As}, \mathrm{Co}, \mathrm{Hg}, \mathrm{Mn}, \mathrm{Sb}$, $\mathrm{Se}$ and $\mathrm{V}$ are below $1 \mu \mathrm{g} / \mathrm{g}$. Mean concentrations of $\mathrm{Al}$, $\mathrm{Cu}, \mathrm{Fe}, \mathrm{K}$ and $\mathrm{Na}$ are between 5 and $17 \mu \mathrm{g} / \mathrm{g}$. In Table 3, the minimum and maximum values are indicated. It is noted that all elements except $\mathrm{S}$, Se and $\mathrm{Zn}$ showed large differences in their concentration values. The uniformity of $\mathrm{S}$ concentrations in fingernails clearly reflects the fact that $\mathrm{S}$ is a major constituent element in nails. The $\mathrm{S}$ data from this study are compared with several literature data in Table 4; our data are found to be similar to those of Rodushkin and Axelsson (2000), while the values reported by Cheng et al. (1995) and Olabanji et al. (2005) are about 4 times lower than our data and $\mathrm{S}$ values of Jervis et al. (1977) (43 to $360 \mu \mathrm{g} / \mathrm{g}$ ) are anomalously low. Recently, Dittmar et al. (2008) reported that $\mathrm{S}$ contents in nails of healthy Germans $(n=225)$ are about 2.4 to $4.3 \%$ with an average value of $3.3 \%$.

Arsenic concentrations in fingernails determined in this study are low (mean of $0.099 \mu \mathrm{g} / \mathrm{g}$ ), which implies no chronic environmental exposure for the participants. Apparently, the low As content in the drinking-water in Tokyo (As: $<0.001$ to $0.008 \mathrm{mg} / \mathrm{L}$; Suzuki et al. 2004) is reflected in their fingernails. In comparison, As concentration in drinking water in West Bengal, India, was reported to be in the range of 0.1 to $0.23 \mathrm{mg} / \mathrm{L}$ (Mandal et al. 1998) and seem to be reflected in fingernails of West Bengali whose mean As concentration is $7.24 \mu \mathrm{g} / \mathrm{g}$ (Samanta et al.2004), approximately 73 times the mean of this study (As: $0.099 \mu \mathrm{g} / \mathrm{g}$ ). The ratio of As concentrations of drinking water between the two countries (about 100) is comparable to that of their fingernails. This clearly indicates that drinking-water can be a main source of As in fingernails.

Mercury is widely studied because of its toxicity to humans. Dietary intake is the main source of $\mathrm{Hg}$ in humans. Mercury abundances in fingernails obtained in this study (Table 3 ) were found to be about 8 times lower than those reported 20 years ago by Takagi et al. (1988) for Japanese residents $(0.91 \mu \mathrm{g} / \mathrm{g})$. As shown in Table 4, $\mathrm{Hg}$ concentrations in fingernails vary among countries but are mostly below $1 \mu \mathrm{g} / \mathrm{g}$. Apparently, the participants of this study were not exposed to high level of $\mathrm{Hg}$ through dietary intake compared with those reported by Takagi et al. (1988). Rice is a staple food for Japanese, but it only contributes about $1 \%$ of total $\mathrm{Hg}$ intake because of low concentration of $\mathrm{Hg}$ (below $1 \mathrm{ng} / \mathrm{g}$, Nakagawa \&Yumita 1998). According to Nakagawa et al. (1997), major Hg intakes of Japanese people are from fish and shellfish, which contribute about $97 \%$ of the total $\mathrm{Hg}$ intake from all foods. 
TABLE 2. Results for reference materials and comparison with literature values. All values are in $\mu \mathrm{g} / \mathrm{g}$ (dry mass basis)

\begin{tabular}{|c|c|c|c|c|c|c|c|c|c|c|c|c|}
\hline \multirow{3}{*}{$\begin{array}{c}\text { Element } \\
\frac{\mathrm{Na}}{}\end{array}$} & \multicolumn{12}{|c|}{ NIES No. 5 Human hair } \\
\hline & \multicolumn{3}{|c|}{ This work } & \multicolumn{3}{|c|}{ Saiki et al. (1998) } & \multicolumn{3}{|c|}{ Abugassa et al. (1999) } & \multicolumn{3}{|c|}{ Certified } \\
\hline & 35.8 & \pm & 3.6 & 24 & \pm & 4 & 27.1 & \pm & 0.1 & 26 & \pm & 1 \\
\hline $\mathrm{Mg}$ & 235 & \pm & 59 & 308 & \pm & 36 & 32.4 & \pm & 0.9 & 208 & \pm & 10 \\
\hline $\mathrm{Al}$ & 259 & \pm & 21 & 295 & \pm & 45 & 4.60 & \pm & 0.06 & & 240 & \\
\hline $\mathrm{S}$ & 45100 & \pm & 2030 & & & & 209 & \pm & 4 & & & \\
\hline $\mathrm{Cl}$ & 250 & \pm & 3 & 252 & \pm & 10 & 154 & \pm & 1 & 34 & 250 & 3 \\
\hline $\mathrm{K}$ & 35.1 & \pm & 2.4 & 30 & \pm & 3 & 1.40 & \pm & 0.02 & 728 & \pm & 30 \\
\hline $\mathrm{Ca}$ & 620 & \pm & 34 & 820 & \pm & 44 & 0.093 & \pm & 0.001 & & & \\
\hline $\mathrm{V}$ & 0.549 & \pm & 0.078 & 0.55 & \pm & 0.07 & 3.90 & \pm & 0.04 & 5.2 & \pm & 0.3 \\
\hline $\mathrm{Mn}$ & 5.12 & \pm & 0.30 & 5.00 & \pm & 0.02 & & & & 225 & \pm & 9 \\
\hline $\mathrm{Fe}$ & 223 & \pm & 13 & 197 & \pm & 19 & & & & & \pm & \\
\hline Co & 0.103 & \pm & 0.014 & 0.108 & \pm & 0.002 & & & & & 0.100 & \\
\hline $\mathrm{Cu}$ & 15.5 & \pm & 3.7 & 13.4 & \pm & 1.9 & & & & 16.3 & \pm & 1.2 \\
\hline $\mathrm{Zn}$ & 160 & \pm & 5 & 162 & \pm & 5 & & & & 169 & \pm & 10 \\
\hline As & 0.083 & \pm & 0.020 & 0.088 & \pm & 0.001 & & & & & & \\
\hline $\mathrm{Se}$ & 1.27 & \pm & 0.06 & 1.47 & \pm & 0.16 & & & & & 1.40 & \\
\hline $\mathrm{Ag}$ & 0.104 & \pm & 0.045 & & & & & & & & & \\
\hline $\mathrm{Sb}$ & 0.060 & \pm & 0.015 & 0.066 & \pm & 0.003 & & & & & 0.070 & \\
\hline $\mathrm{Hg}$ & 1.04 & \pm & 0.06 & 4.25 & \pm & 0.24 & & & & 4.4 & \pm & 0.4 \\
\hline \multirow{2}{*}{ Element } & \multicolumn{12}{|c|}{ NIST 1577a Bovine Liver } \\
\hline & \multicolumn{3}{|c|}{ This work } & \multicolumn{3}{|c|}{ Andrási et al. (1993) } & \multicolumn{3}{|c|}{ Wasim et al. (2002) } & \multicolumn{3}{|c|}{ Certified } \\
\hline $\mathrm{Na}$ & 2390 & \pm & 200 & 2030 & \pm & 100 & 2500 & \pm & 144 & 2430 & \pm & 130 \\
\hline $\mathrm{Mg}$ & 601 & \pm & 47 & 650 & \pm & 30 & 614 & \pm & 19 & 600 & \pm & 15 \\
\hline $\mathrm{Al}$ & & & & & & & & & & & 2 & \\
\hline S & 7610 & \pm & 267 & 7160 & \pm & 200 & & & & 7800 & \pm & 100 \\
\hline $\mathrm{Cl}$ & 2790 & \pm & 210 & & & & 2780 & \pm & 87 & 2800 & \pm & 100 \\
\hline $\mathrm{K}$ & 9400 & \pm & 520 & 9540 & \pm & 180 & 9840 & \pm & 75 & 9960 & \pm & 70 \\
\hline $\mathrm{Ca}$ & 121 & \pm & 5 & & & & & & & 120 & \pm & 7 \\
\hline $\mathrm{V}$ & 0.108 & \pm & 0.005 & & & & & & & 0.099 & \pm & 0.008 \\
\hline $\mathrm{Mn}$ & 9.49 & \pm & 0.54 & 8.9 & \pm & 1.4 & 9.8 & \pm & 0.7 & 9.9 & \pm & 0.8 \\
\hline $\mathrm{Fe}$ & 174 & \pm & 10 & 172 & \pm & 20 & 195 & \pm & 22 & 194 & \pm & 20 \\
\hline Co & 0.240 & \pm & 0.012 & & & & & & & 0.21 & \pm & 0.05 \\
\hline $\mathrm{Cu}$ & 157 & \pm & 6 & 148 & \pm & 6 & & & & 158 & \pm & 7 \\
\hline $\mathrm{Zn}$ & 113 & \pm & 3 & 113 & \pm & 7 & 124 & \pm & 8 & 123 & \pm & 8 \\
\hline As & 0.051 & \pm & 0.031 & & & & 0.052 & \pm & 0.005 & 0.047 & \pm & 0.006 \\
\hline $\mathrm{Se}$ & 0.788 & \pm & 0.062 & & & & & & & 0.71 & \pm & 0.07 \\
\hline $\mathrm{Ag}$ & 0.056 & \pm & 0.030 & & & & & & & 0.04 & \pm & 0.01 \\
\hline $\mathrm{Sb}$ & 0.005 & \pm & 0.002 & & & & & & & & 0.003 & \\
\hline $\mathrm{Hg}$ & 0.006 & \pm & 0.002 & & & & & & & 0.004 & \pm & 0.002 \\
\hline
\end{tabular}

COMPARISONS OF ELEMENTAL CONCENTRATIONS IN FINGERNAILS WITH DIETARY INTAKES AND REFERENCE MAN

Dietary intake of chemical elements plays an essential role in human nutrition and health. In recent years, collaborative studies joined by many countries have been conducted to determine the reference values for daily dietary intake of chemical elements. In Figure 1, elemental concentrations in nail samples are compared with elemental dietary intakes and elemental compositions of reference man. In this figure, mean values from this work and literatures for nail samples were plotted by arranging the elements in increasing atomic numbers. All values plotted are assumed for healthy individuals representing individual countries. Based on their contents, elements determined can be divided into two groups: $\mathrm{Na}, \mathrm{Mg}, \mathrm{Al}, \mathrm{S}, \mathrm{Cl}, \mathrm{K}, \mathrm{Ca}, \mathrm{Fe}$ and $\mathrm{Zn}$ vs. V, Mn, Co, Cu, $\mathrm{As}, \mathrm{Se}, \mathrm{Ag}, \mathrm{Sb}$ and $\mathrm{Hg}$. Our data showed lower values for elements $\mathrm{Na}, \mathrm{Al}, \mathrm{K}, \mathrm{V}, \mathrm{Sb}$ and $\mathrm{Hg}$ than the literature values. It is noticeable that the data for Japanese reported by Takagi et al. (1988) have higher concentrations of $\mathrm{Na}$, $\mathrm{Al}, \mathrm{K}, \mathrm{V}, \mathrm{Sb}$ and $\mathrm{Hg}$ than the data of this study. This may be due to lower dietary intake of these elements for the individuals of this study.

From Table 4, it is found that the transition elements $\mathrm{V}, \mathrm{Mn}, \mathrm{Fe}, \mathrm{Co}, \mathrm{Cu}$ and $\mathrm{Zn}$ show an interesting distribution in nails, being different from those for the other elements plotted in Figure 1. When their concentrations are compared among those of dietary intake, reference man (except for V; Iyengar 1998) and literature values, 
TABLE 3. Elemental concentrations ( $\mu \mathrm{g} / \mathrm{g}$ dry mass) in fingernail samples $(n=18)$

\begin{tabular}{ccccccc}
\hline Element & Geometric Mean & Standard deviation $(1 \sigma)$ & RSD $(\%)$ & Min. & Max. & Max/Min \\
\hline $\mathrm{Na}$ & 16.8 & 31.6 & 188 & 1.79 & 114 & 63.7 \\
$\mathrm{Mg}$ & 77.6 & 35.1 & 45.2 & 28.4 & 174 & 6.13 \\
$\mathrm{Al}$ & 8.62 & 11.3 & 131 & 0.78 & 49.6 & 63.6 \\
$\mathrm{~S}$ & 33600 & 5340 & 15.9 & 26600 & 48900 & 1.84 \\
$\mathrm{Cl}$ & 98.9 & 128 & 129 & 29.6 & 502 & 17.0 \\
$\mathrm{~K}$ & 11.9 & 32.4 & 272 & 2.65 & 144 & 54.3 \\
$\mathrm{Ca}$ & 464 & 281 & 60.6 & 116 & 1040 & 8.97 \\
$\mathrm{~V}$ & 0.0176 & 0.0197 & 112 & 0.0035 & 0.082 & 23.4 \\
$\mathrm{Mn}$ & 0.482 & 0.475 & 98.5 & 0.117 & 1.76 & 15.0 \\
$\mathrm{Fe}$ & 17.7 & 10.3 & 58.2 & 10.2 & 41.2 & 4.04 \\
$\mathrm{Co}$ & 0.0191 & 0.0312 & 1.63 & 0.0052 & 0.135 & 26.0 \\
$\mathrm{Cu}$ & 5.18 & 1.72 & 33.2 & 2.96 & 10.4 & 3.51 \\
$\mathrm{Zn}$ & 104 & 21 & 20.2 & 80.4 & 159 & 1.60 \\
$\mathrm{As}$ & 0.0993 & 0.0391 & 38.5 & 0.051 & 0.182 & 3.57 \\
$\mathrm{Se}$ & 0.998 & 0.150 & 15.0 & 0.801 & 1.26 & 1.57 \\
$\mathrm{Ag}$ & 0.184 & 0.109 & 98.2 & 0.033 & 7.57 & 229 \\
$\mathrm{Sb}$ & 0.0073 & 0.0069 & 79.0 & 0.0019 & 0.0332 & 17.5 \\
$\mathrm{Hg}$ & 0.112 & 0.047 & 50.7 & 0.068 & 0.224 & 3.29 \\
\hline
\end{tabular}

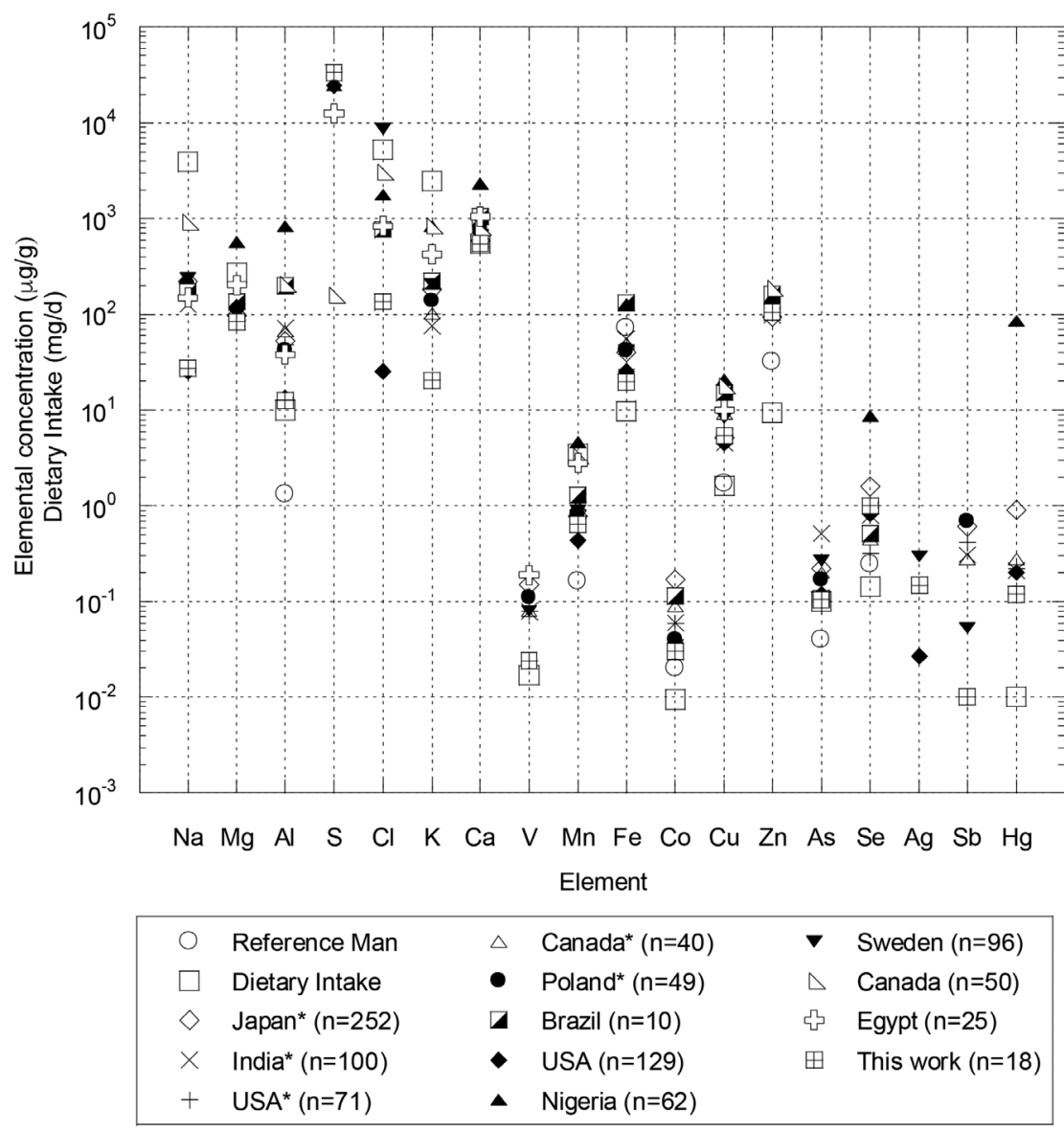

FIGURE 1. Comparisons of mean elemental concentrations of this study with those of literatures, dietary intake (Iyengar 1998; Parr et al. 2006; Shiraishi 2005) and reference man (Iyengar 1998). Elements are arranged according to atomic numbers. The numbers in parentheses indicate sample numbers. The data for countries indicated with asterisks were from Takagi et al. (1988). The values for elemental concentrations and dietary intakes are sharing the same $y$-axis 


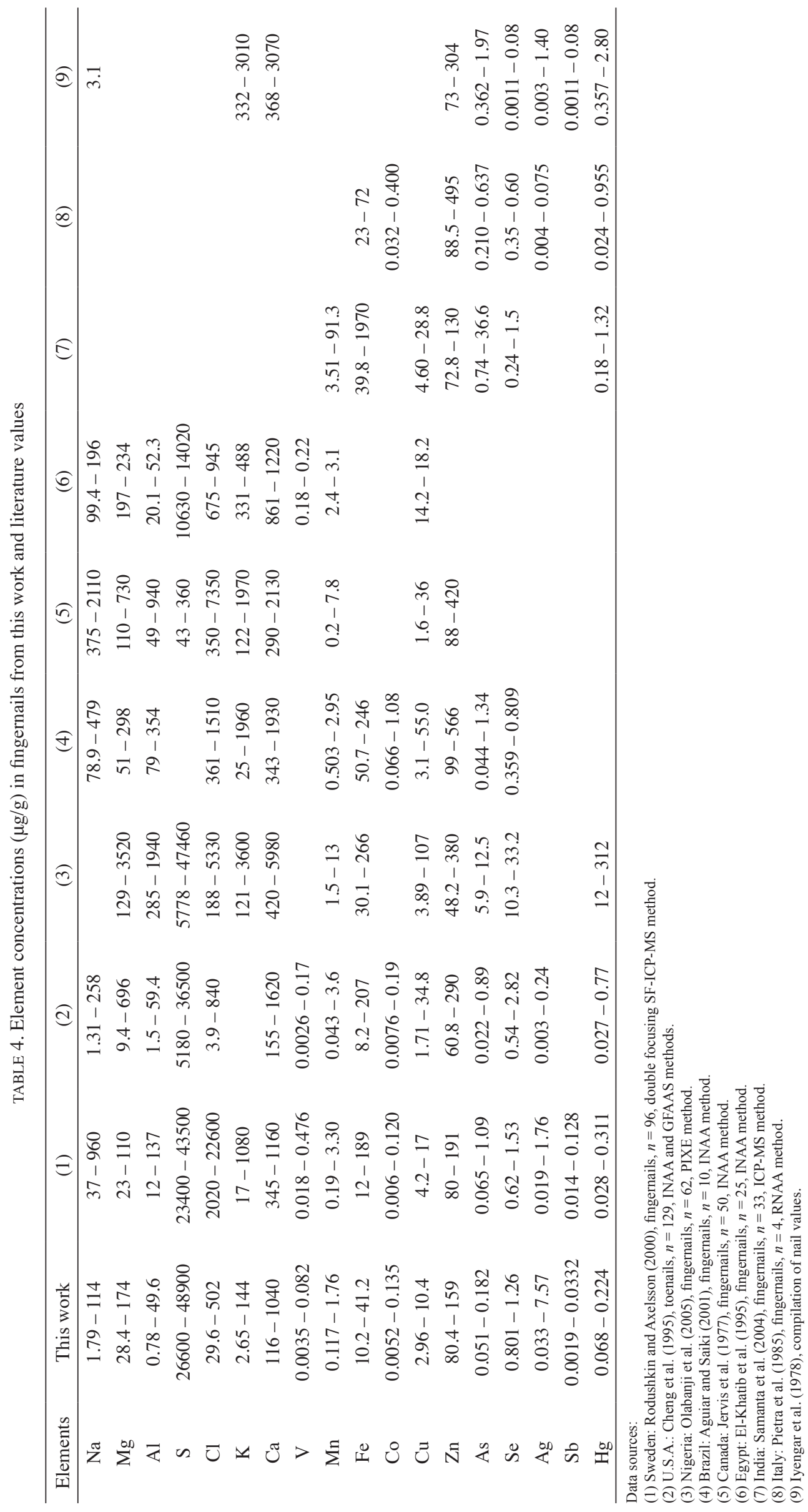




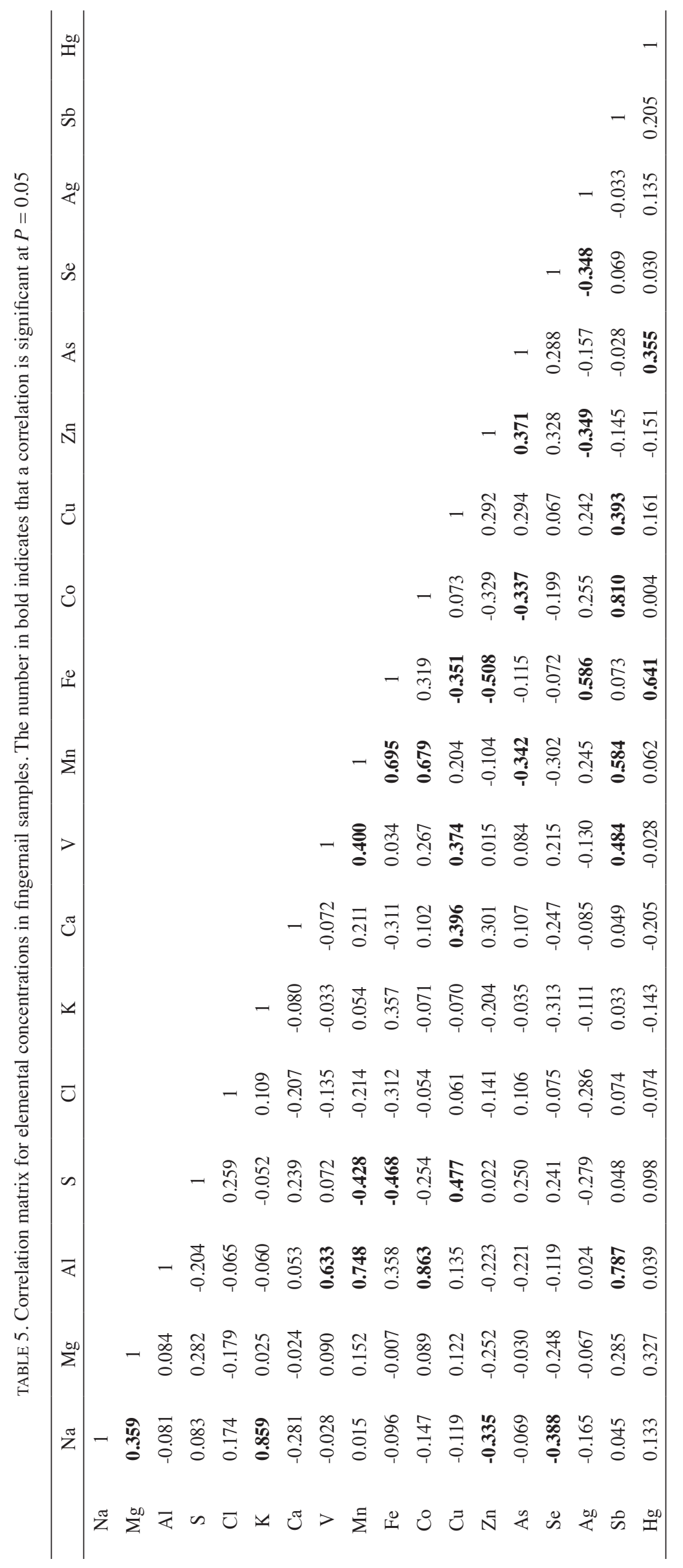


these elements behave in the same order, implying the mutual relationship between dietary intake and elemental accumulation in nails. From the present observation, it seems likely that dietary intake exerts a greater influence to the presence of $\mathrm{V}, \mathrm{Mn}, \mathrm{Fe}, \mathrm{Co}, \mathrm{Cu}$ and $\mathrm{Zn}$ in human bodies than other factors such as environment, living habits, genders and geography. Similar elemental patterns of nails, dietary intake and reference man lead to an understanding that the absorption of these elements is counterbalanced by their excretions in human body. In addition, Iyengar (1998) pointed out that elements not physiologically controlled in blood are expected to show variations similar to constituents in the food. For the other elements in Figure 1, different population groups showed variable concentrations in nails, meaning that these elements are more susceptible to changes due to body physiological control, environment, living habits and other factors. Thus, nail serve as a good biomonitor for chemical elements present in human body.

\section{CORRELATIONS BETWEEN ELEMENT CONCENTRATIONS IN FINGERNAILS}

Correlation coefficients showed potential relationships or interactions between two elements in nail samples and examples have been reported by Chaudhary et al. (1995), Cheng et al. (1995), Samanta et al. (2004) and Slotnick et al. (2005). Correlation coefficients of this study are shown as correlation matrix in Table 5. Through the use of $t$-test, significant correlations at the level $P=0.05$ for the elements were identified in bold in Table 5. The elements $\mathrm{Na}$ and $\mathrm{K}$ showed the highest correlation coefficients $(r=0.859, P$ $<0.001)$ among all the other pairs of the elements. There are also significant correlations between $\mathrm{Na}$ with $\mathrm{Mg}(r=$ $0.359)$ and between $\mathrm{Na}$ and $\mathrm{Se}(r=-0.388)$. The elements $\mathrm{K}, \mathrm{Na}$ and $\mathrm{Mg}$ are abundant in biological tissues and may behave coherently. The element Al correlates significantly $(P<0.001)$ with $\mathrm{Co}, \mathrm{Mn}, \mathrm{Sb}$ and $\mathrm{V}$, which may reflect exposures to different sources because dietary intakes of these elements are very little (below $10 \mathrm{mg} / \mathrm{d}$ ). Cheng et al. (1995) reported that $\mathrm{Al}$ correlate with $\mathrm{Mn}$ and $\mathrm{V}$ in toenails. It is said that excessive dietary intake of $\mathrm{Zn}$ can cause $\mathrm{Cu}$ deficiency (Fraga 2005). Considering no negative correlation between $\mathrm{Zn}$ and $\mathrm{Cu}$ in this study, it is implied that both elements are in good balance in participating people. For elements $\mathrm{As}$ and $\mathrm{Hg}$, a significant correlation was observed in this study. Because this study involves healthy and uncontaminated individuals, the correlation of As and $\mathrm{Hg}$ suggested that there is minimal exposure to $\mathrm{As}$ and $\mathrm{Hg}$ from dietary intakes. The element $\mathrm{Ag}$ is found to correlate positively with $\mathrm{Fe}$ and negatively with $\mathrm{Zn}$ and $\mathrm{Se}$. The element $\mathrm{Cl}$ has no significant correlation with other elements determined in this study. Further study on the inter-element interactions is needed to explain the correlations of chemical elements observed in nails.

\section{CONCLUSION}

In this study, fingernails from 18 healthy individuals have been collected and analyzed. The use of INAA has been successfully performed for the elemental determination of nail samples and results are verified with quality control materials. The $\mathrm{Hg}$ level found in this study is lower than that reported 20 years ago, highly due to strict environmental control in Japan. The elemental concentrations of $\mathrm{Co}, \mathrm{Cu}$, $\mathrm{Fe}, \mathrm{Mn}, \mathrm{V}$ and $\mathrm{Zn}$ in fingernails were found to reflect the dietary intakes. These elements showed similar patterns to those for dietary intakes and reference man. This finding appeals the effectiveness of nails as a biomonitor. A correlation matrix displayed a complex relationship among elements in nails. Significant correlations were found between $\mathrm{Na}$ and $\mathrm{K}$ and $\mathrm{Na}$ and $\mathrm{Mg}$. The results of this study could represent the current background level for the people of Tokyo, Japan.

\section{ACKNOWLEDGEMENTS}

The authors would like to thank the participants of this study for providing their fingernail samples. One of the authors (B.S.W.) greatly appreciates the Ministry of Education, Culture, Science and Technology of Japan (MEXT) for funding. Neutron irradiation was made possible through the inter-university program for the cooperative use of the JAEA reactors supported by University of Tokyo and MEXT.

\section{REFERENCES}

Abugassa, I., Sarmani, S.B. \& Samat, S.B. 1999. Multielement analysis of human hair and kidney stones by instrumental neutron activation analysis with the $\mathrm{k}_{0}$-standardization method. Applied Radiation Isotopes 50: 989-994.

Aguiar,A.R. \& Saiki, M. 2001. Determination of trace elements in human nail clippings by neutron activation analysis. Journal of Radioanalytical and Nuclear Chemistry 249: 413-416.

Andrási, E., Dózsa, A., Bezur, L., Ernyei, L. \& Molnár, Z. 1993. Characterization of biological RMs for potential use in human brain analysis. Fresenius Journal Analytical Chemistry 345: 340-342.

Chaudhary, K., Ehmann, W.D., Rengan, K. \& Markesbery, W.R. 1995. Trace element correlations with age and sex in human fingernails. Journal of Radioanalytical and Nuclear Chemistry 195: 51-56.

Cheng, T.P., Morris, J.S., Koirtyohann, S.R., Spate, V.L. \& Baskett, C.K. 1995. Study of the correlation of trace elements in carpenters' toenails. Journal of Radioanalytical and Nuclear Chemistry 195: 31-42.

Daniel, C.R. III, Piraccini, B.M. \& Tosti, A. 2004. The nail and hair in forensic science. Journal of the American Academy of Dermatology 50: 258-261.

Dittmar, M., Dindorf, W. \& Banerjee, A. 2008. Organic elemental composition in fingernail plates varies between sexes and changes with increasing age in healthy humans. Gerontology 54: 100-105.

El-Khatib, A.M., Bahnassy, A.A. \& Denton, M. 1995. Trace elements in the human scalp hair and finger nails as affected by infection with Schistosoma Mansoni. Radiation Physics and Chemistry 45: 141-145.

Fraga, C.G. 2005. Relevance, essentiality and toxicity of trace elements in human health. Molecular Aspects of Medicines 26: $235-244$. 
Hayashi, M., Yamamoto, K., Yoshimura, M., Hayashi, H. \& Shitara, A. 1993. Cadmium, lead and zinc concentrations in human fingernails. Bulletin of Environmental Contamination and Toxicology 50: 547-553.

Iyengar, G.V. 1998. Reevaluation of the trace element content in reference man. Radiation Physics and Chemistry 51: 545-560.

Iyengar, G.V., Kollmer, W.E. \& Bowen, H.J.M. 1978. The Elemental Composition of Human Tissues and Body Fuids. New York: Verlag Chemie, Weinheim. p. 151.

Jervis, R.E., Hancock, R.G.V., Hill, D.E. \& Isles, K. 1977. Biomedical and health studies with the new Canadian slowpoke reactor. Journal of Radioanalytical Chemistry 37: 463-471.

Mandal, B.K., Roychowdhury, T., Samanta, G., Mukherjee, D.P., Chanda, C.R., Saha, K.C., \& Chakraborti, D. 1998. Impact of safe water for drinking and cooking on five arsenic-affected families for 2 years in West Bengal, India. Science of the Total Environment 218: 185-201.

Menezes, M.Â.B.C., Maia, E.C.P., Albinati, C.C.B., Sabino, C.V.S. \& Batista, J.R. 2004. How suitable are scalp hair and toenail as biomonitors? Journal of Radioanalytical and Nuclear Chemistry 249: 81-86.

Morris, J.S., Spate, V.L. \& Ngwenyama, R.A. 2006. Determinants of selenium in the toenail biomonitor. Journal of Radioanalytical and Nuclear Chemistry 269: 283-290.

Nakagawa, R.\& Yumita, Y. 1998. Change and behavior of residual mercury in paddy soils and rice of Japan. Chemosphere 37: 1483-1487.

Nakagawa, R., Yumita, Y. \& Hiromoto, M. 1997. Total mercury intake from fish and shellfish by Japanese people. Chemosphere 35: 2909-2913.

Olabanji, S.O.,Ajose, O.A., Makinde, N.O.,Buoso, M.C., Ceccato, D., DePoli, M. \& Moschini, G. 2005. Characterization of human fingernail elements using PIXE technique. Nuclear Instruments and Methods in Physics Research Section B 240: 895-907.

Parr, R.M., Aras, N.K. \& Iyengar, G.V. 2006. Dietary intakes of essential trace elements: Results from total diet studies supported by the IAEA. Journal of Radioanalytical and Nuclear Chemistry 270: 155-161.

Pietra, R., Sabbioni, E., Ubertalli, L., Orvini, E., Vocaturo, G., Colombo, F. \& Zanoni, M. 1985. Trace elements in tissues of a worker affected by rare earths pneumoconiosis, a study carried out by neutron activation analysis. Journal of Radioanalytical and Nuclear Chemistry 92: 247-259.

Rodushkin, I. \& Axelsson, M.D. 2000. Application of double focusing sector field ICP-MS for multielemental characterizaqtion of human hair and nails. Part II. A study of the inhabitants of northern Sweden. Science of the Total Environment 262: 21-36.

Saiki, M., Vasconcellos, M.B.A., deArauz, L.J. \& Fulfaro, R. 1998. Determination of trace elements in human head hair by neutron activation analysis. Journal of Radioanalytical and Nuclear Chemistry 236: 25-28.
Samanta, G., Sharma, R., Roychowdhury, T. \& Chakraborti, D. 2004. Arsenic and other elements in hair, nails, and skinscales of arsenic victims in West Bengal, India. Science of the Total Environment 326: 33-47.

Shiraishi, K. 2005. Dietary intakes of eighteen elements and ${ }^{40} \mathrm{~K}$ in eighteen food categories by Japanese subjects. Journal of Radioanalytical and Nuclear Chemistry 266: 61-69.

Slotnick, M.J., Nriagu, J.O., Johnson, M.M., Linder, A.M., Savoie, K.L., Jamil, H.J. \& Hammad, A.S. 2005. Profiles of trace elements in toenails of Arab-Americans in the Detroit area, Michigan. Biological Trace Element Research 107: 113-126.

Suzuki, T., Igarashi, T., Inaba, M., Usami, M. \& Yasuda, K. 2004. The water quality of private water supplies utilizing groundwater. Tokyo Metropolitan Institute of Public Health Annual Report 55: 269-273.

Takagi, Y., Matsuda, S., Imai, S., Ohmori, Y., Masuda, T., Vinson, J.A., Mehra, M.C., Puri, B.K. \& Kaniewski,A. 1988. Survey of trace elements in human nails: An international comparison. Bulletin of Environmental Contamination and Toxicology 41: 690-695.

Wasim, M., Rahman, A., Zaidi, J.H., Waheed, S. \& Ahmad, S. 2002. Neutron activation analysis of IAEA proposed certified reference material IAEA-407 (North Sea Fish Homogenate). Journal of Radioanalytical and Nuclear Chemistry 254: 219-222.

\section{B.S. Wee*}

Department of Chemistry

Faculty of Resource Science and Technology

Universiti Malaysia Sarawak

94300 Kota Samarahan, Sarawak Bumi Kenyalang

Malaysia

M. Ebihara

Department of Chemistry

Graduate School of Science and Engineering

Tokyo Metropolitan University

Minami Ohsawa 1-1, Hachioji, 192-0397 Tokyo

Japan

*Corresponding author; email: swboon@unimas.my

Received: 28 June 2016

Accepted: 18 September 2016 